Review Article

\title{
The Essential Element Manganese, Oxidative Stress, and Metabolic Diseases: Links and Interactions
}

\author{
Longman Li $\mathbb{D}^{1}$ and Xiaobo Yang $\mathbb{D}^{1,2}$ \\ ${ }^{1}$ Department of Occupational Health and Environmental Health, School of Public Health, Guangxi Medical University, Nanning, \\ Guangxi, China \\ ${ }^{2}$ Center for Genomic and Personalized Medicine, Guangxi Medical University, Nanning, Guangxi, China
}

Correspondence should be addressed to Xiaobo Yang; yangx@gxmu.edu.cn

Received 25 October 2017; Revised 10 February 2018; Accepted 12 March 2018; Published 5 April 2018

Academic Editor: Pan Chen

Copyright (c) 2018 Longman Li and Xiaobo Yang. This is an open access article distributed under the Creative Commons Attribution License, which permits unrestricted use, distribution, and reproduction in any medium, provided the original work is properly cited.

\begin{abstract}
Manganese $(\mathrm{Mn})$ is an essential element that is involved in the synthesis and activation of many enzymes and in the regulation of the metabolism of glucose and lipids in humans. In addition, $\mathrm{Mn}$ is one of the required components for Mn superoxide dismutase (MnSOD) that is mainly responsible for scavenging reactive oxygen species (ROS) in mitochondrial oxidative stress. Both Mn deficiency and intoxication are associated with adverse metabolic and neuropsychiatric effects. Over the past few decades, the prevalence of metabolic diseases, including type 2 diabetes mellitus (T2MD), obesity, insulin resistance, atherosclerosis, hyperlipidemia, nonalcoholic fatty liver disease (NAFLD), and hepatic steatosis, has increased dramatically. Previous studies have found that ROS generation, oxidative stress, and inflammation are critical for the pathogenesis of metabolic diseases. In addition, deficiency in dietary $\mathrm{Mn}$ as well as excessive $\mathrm{Mn}$ exposure could increase ROS generation and result in further oxidative stress. However, the relationship between $\mathrm{Mn}$ and metabolic diseases is not clear. In this review, we provide insights into the role Mn plays in the prevention and development of metabolic diseases.
\end{abstract}

\section{Introduction}

Manganese (Mn) is an essential element in the human body that is mainly obtained from food and water. Mn is absorbed through the gastrointestinal tract and then transported to organs enriched in the mitochondria (in particular the liver, pancreas, and pituitary) where it is rapidly concentrated [1]. Furthermore, $\mathrm{Mn}$ is involved in the synthesis and activation of many enzymes (e.g., oxidoreductases, transferases, hydrolases, lyases, isomerases, and ligases); metabolism of glucose and lipids; acceleration in the synthesis of protein, vitamin $\mathrm{C}$, and vitamin $\mathrm{B}$; catalysis of hematopoiesis; regulation of the endocrine; and improvement in immune function [2]. Moreover, Mn metalloenzymes including arginase, glutamine synthetase, phosphoenolpyruvate decarboxylase, and Mn superoxide dismutase (MnSOD) also contribute to the metabolism processes listed above and reduce oxidative stress against free radicals (Figure 1).
However, environmental or occupational Mn overexposure is harmful to human health, especially in at-risk populations such as miners, welders, and steel makers. According to data from the Mineral Commodity Summaries released by the US Geological Survey in 2016, South Africa, China, and Australia accounted for $67 \%$ of the total Mn mined (18 million tons) in the world in 2015. Mn ore mining and its processing cause air and water pollution, threatening the health of workers and general populations residing near factories through oral ingestion and inhalation as well as dermally and intravenously. Acute Mn exposure can lead to manganism, and chronic Mn exposure causes an extrapyramidal syndrome with features resembling those found in Parkinson's disease and postencephalitic parkinsonism [3].

The prevalence of metabolic diseases, including type 2 diabetes mellitus (T2DM), obesity, insulin resistance, atherosclerosis, hyperlipidemia, nonalcoholic fatty liver disease (NAFLD), and hepatic steatosis, has increased dramatically 


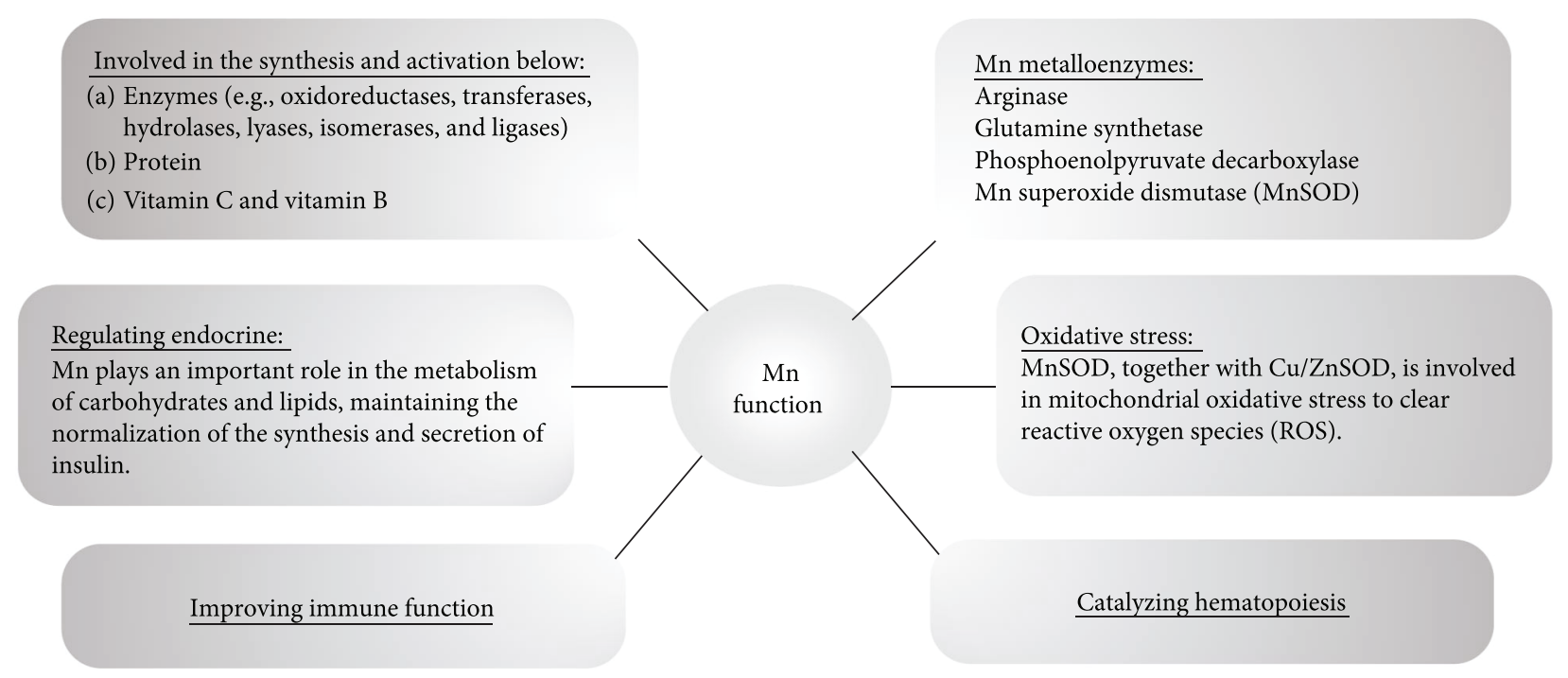

Figure 1: Physiological roles of Mn.

over the past few decades [4]. These metabolic disorders are usually caused by the clustering of metabolic syndrome (MetS). The criteria for identifying MetS include three of five markers: abdominal obesity, impaired carbohydrate metabolism, high blood pressure, and dyslipidemia, including elevated levels of triglycerides and decreased levels of high-density lipoprotein (HDL) [5]. In addition, many studies have shown that metabolic diseases are associated with oxidative stress and inflammation [6-12].

$\mathrm{Mn}$ is a component or activator of some enzymes, mostly antioxidants, and plays an important role in metabolisms of carbohydrates and lipids, even in maintaining the normalization of the synthesis and secretion of insulin as well. Therefore, Mn may have protective effects on the occurrence of MetS [13].

Importantly, $\mathrm{Mn}$ is a required component of MnSOD for reducing mitochondrial oxidative stress. Mitochondria are the major place where physiological and pathological cellular reactive oxygen species (ROS) are produced. When excessive ROS accumulate abnormally, it would contribute to the oxidative damage found in several neuropathological conditions related to enhanced glucocorticoid expression, which plays an important role in regulating the biosynthesis and metabolism of carbohydrates, lipids, and proteins [14]. Additionally, MnSOD is the primary antioxidant that scavenges superoxide formed within the mitochondria and protects against oxidative stress $[15,16]$. If mitochondria are impaired or dysfunctional, ROS production will be further increased and will exacerbate the oxidative stress in mitochondria [17] (Figure 2).

Nevertheless, research in molecular biology or population related to the role of $\mathrm{Mn}$ in procession of metabolic diseases via mitochondrial oxidative stress is limited and inconsistent. Mn deficiency and intoxication are both associated with adverse metabolic and neuropsychiatric effects $[18,19]$. Experimentally induced Mn deficiency caused a number of detrimental effects, such as impaired growth, poor bone formation and skeletal defects, reduced fertility and birth defects, abnormal glucose tolerance, and altered lipid and carbohydrate metabolism in both animals and humans [2]. By inhibiting mitochondrial complex I and II respiration as well as inducing permeability transition, excessive $\mathrm{Mn}$ accumulated in mitochondria could disrupt mitochondrial homeostasis and cause mitochondrial dysfunction [20-22]. In the study about metabolic gene polymorphisms and susceptibility to occupational chronic manganism, it has been found that individuals with homozygote polymorphism (L/L) of the cytochrome P450 2D6L gene (CYP2D6L) might decrease the risk of chronic manganism compared with the wild type (Wt/Wt) [23].

In this review, we summarize current hypotheses and research to explore the relationship between $\mathrm{Mn}$ and metabolic diseases and reveal how Mn affects the metabolism in both molecular biology and population studies.

\section{Mn and Metabolic Syndrome}

The prevalence of MetS is increasing throughout the world [24]. Recently, criteria to define MetS have been steeped in controversy, but MetS is generally defined by five components: central obesity, raised triglycerides, reduced HDLcholesterol, raised blood pressure, and raised fasting plasma glucose [25]. The most important role of MetS is to help identify high-risk individuals of both T2DM and cardiovascular disease (CVD) [25].

Oxidative stress is a common risk factor for the pathogenesis of MetS components. Insulin resistance is generally accepted as the first level of metabolic changes in patients with MetS, while the state of chronic low-level inflammation and oxidative stress are second-level abnormalities [26]. Oxidative stress has been associated with all the individual components of MetS and with the onset of cardiovascular complications in subjects with MetS [26-29]. 


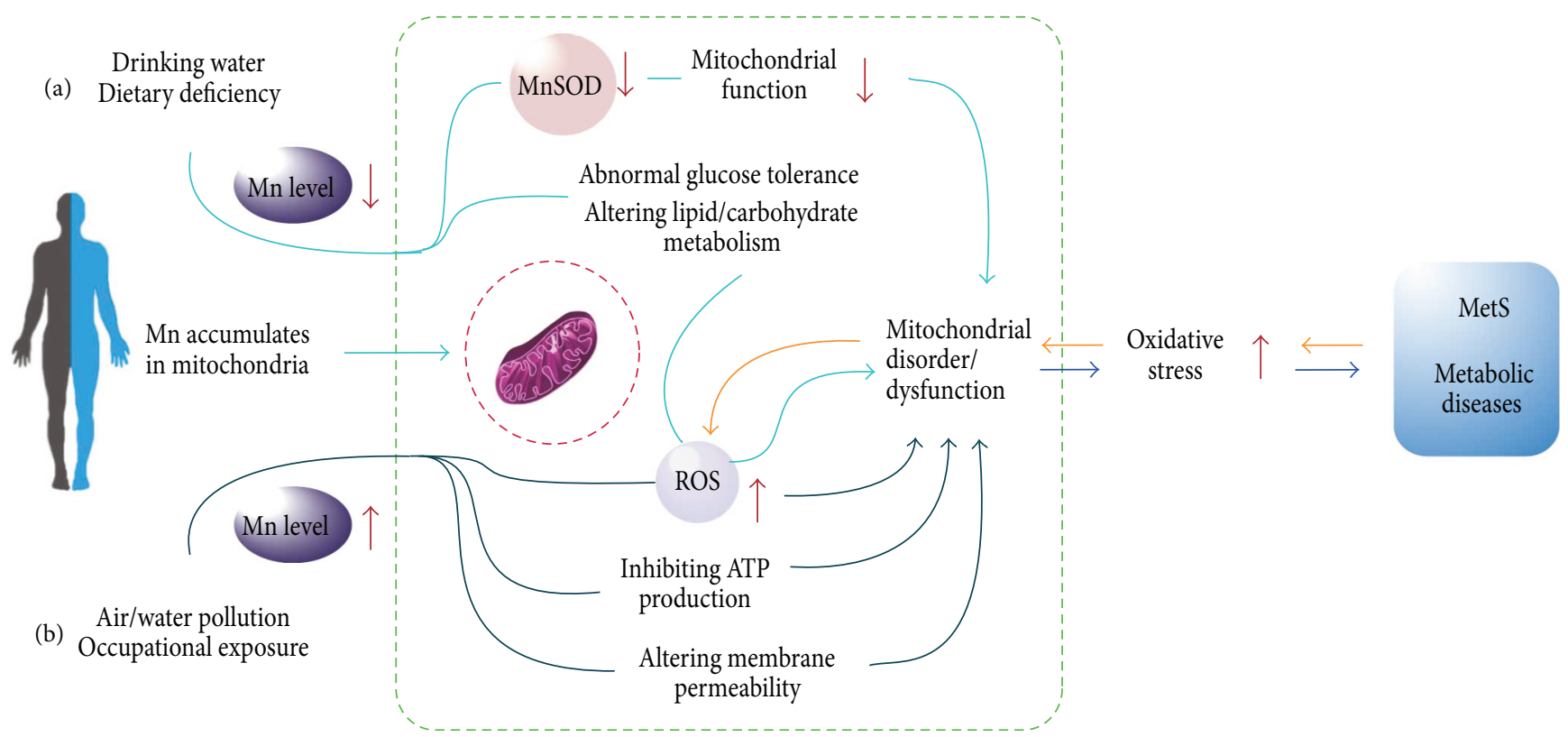

Figure 2: The mechanisms of Mn in metabolic diseases via oxidative stress. (a) Mn deficiency will cause a number of detrimental effects, such as impaired growth, poor bone formation and skeletal defects, reduced fertility and birth defects, abnormal glucose tolerance, and altered lipid and carbohydrate metabolism in both animals and humans. Therefore, Mn deficiency might lead to mitochondrial dysfunction or disorder via decreasing MnSOD level and altering lipid and carbohydrate metabolism. (b) Mn overloaded may disrupt normal mitochondrial function by increasing mitochondrial ROS, inhibiting ATP production, and altering membrane permeability; further result in mitochondrial dysfunction or disorder; and finally cause MetS or metabolic diseases. Excessive ROS and oxidative stress would lead to MetS or metabolic diseases directly. If MetS or metabolic diseases happen, it will in turn increase ROS production and oxidative stress and accelerate mitochondrial dysfunction or disorder.

So far, a few researches explore the association between Mn and MetS (Table 1). Higher Mn intake was associated with decreased risk of MetS in men but increased risk in women; Chinese researchers also found that $\mathrm{Mn}$ intake was inversely associated with MetS components including abdominal obesity and hypertriacylglycerolaemia in men, but positively associated with low HDL-cholesterol in both men and women [30]. In Korean women with MetS, dietary Mn intake was significantly lower than that of the healthy control group; the same result was also found in women subjects with high blood pressure only [31]. Moreover, another Chinese study indicated that daily intake of $\mathrm{Mn}$ was lower in individuals with a higher number of MetS components and a lower risk of developing MetS in the second, third, and highest quintiles of $\mathrm{Mn}$ intake compared to the lowest quintile, adjusted for age, sex, and energy intake [32]. However, blood and urine Mn concentrations were not significantly associated with MetS [5,33].

However, these epidemiologic studies did not consider potential confounding factors, such as changing dietary habits of patients based on their nutritional knowledge about the MetS components, and did not exclude the MetS patients who have accepted therapy. That might be the main causes of previous data showing an inverted relation between $\mathrm{Mn}$ intake and risk for MetS. Besides, it is difficult to confirm the association between dietary intake and MetS risk, because the bioavailability of dietary nutrients would be influenced by some factors, for instance, characteristics of the food source, interactions with other dietary factors, cooking conditions, and various subject characteristics.

\section{Mn and Type 2 Diabetes Mellitus/ Insulin Resistance}

T2DM accounts for over $90 \%$ of global diabetes cases compared to type 1 diabetes. T2DM is characterized by hyperglycemia caused by insulin resistance and/or abnormal insulin secretion, either of which may predominate [34].

Several pathogenic pathways activated in diabetes such as ROS, which are generated by high glucose levels, are responsible for metabolic abnormalities and chronic complications [35]. Moreover, oxidative stress can result in impaired islet beta cell function, cause insulin resistance, and finally lead to T2DM and obesity [7, 8]. Normalizing levels of mitochondrial ROS prevents three pathways of hyperglycaemic damage including glucose-induced activation of protein kinase C, formation of advanced glycation end-products, sorbitol accumulation, and $\mathrm{NF} \kappa \mathrm{B}$ activation [36]. Mitochondrial dysfunction has divergent, cell type-dependent effects on insulin action [37] and has been proposed to induce insulin resistance through ectopic lipid accumulation secondary to reduced $\beta$-oxidation, which impairs insulin signaling $[38,39]$. In heterozygous MnSOD knockout mice, the MnSOD protein decreased by approximately $70 \%$ in muscle and fat, and glucose tolerance was already impaired after feeding these mice a standard chow [40]. Recent studies using 
TABLE 1: The studies of Mn and MetS.

\begin{tabular}{|c|c|c|c|c|c|c|}
\hline Reference & Country & Study design & Sample size & $\begin{array}{l}\text { Data source/ } \\
\text { sample type }\end{array}$ & & Results \\
\hline \multirow{5}{*}[30]{} & \multirow{5}{*}{ China } & \multirow{5}{*}{$\begin{array}{l}\text { The 5th Chinese } \\
\text { National Nutrition } \\
\text { and Health Survey } \\
\quad(2010-2012)\end{array}$} & \multirow{5}{*}{2111} & \multirow{5}{*}{$\begin{array}{l}\text { Questionnaire } \\
\text { of dietary } \\
\text { Mn intake }\end{array}$} & Men & $\begin{array}{l}\text { A decreased risk of MetS with higher } \\
\text { Mn intake. }\end{array}$ \\
\hline & & & & & Women & $\begin{array}{l}\text { An increased risk of MetS with higher } \\
\text { Mn intake. }\end{array}$ \\
\hline & & & & & & Mn intake was inversely associated with \\
\hline & & & & & $\begin{array}{l}\text { MetS } \\
\text { components }\end{array}$ & $\begin{array}{l}\text { abdominal obesity and } \\
\text { hypertriacylglycerolaemia in men, } \\
\text { but positively associated with low }\end{array}$ \\
\hline & & & & & & HDL-cholesterol in both men and women. \\
\hline & & The Korea National & & & Men & No difference \\
\hline [31] & Korea & $\begin{array}{l}\text { Health and Nutrition } \\
\text { Examination Survey } \\
\quad(2007-2008)\end{array}$ & 5136 & $\begin{array}{l}\text { Questionnaire } \\
\text { of dietary } \\
\text { Mn intake }\end{array}$ & $\begin{array}{l}\text { Women/MetS } \\
\text { components }\end{array}$ & $\begin{array}{l}\text { The women subjects with high blood } \\
\text { pressure showed significantly lower intake } \\
\text { of Mn than did control subjects. }\end{array}$ \\
\hline \multirow[t]{2}{*}{ [32] } & \multirow[t]{2}{*}{ China } & \multirow[t]{2}{*}{ Cross-sectional study } & \multirow[t]{2}{*}{$\begin{array}{l}\text { Cases: } 221 \\
\text { Controls: } 329\end{array}$} & \multirow[t]{2}{*}{$\begin{array}{l}\text { Questionnaire } \\
\text { of dietary } \\
\text { Mn intake }\end{array}$} & Men/women & $\begin{array}{l}\text { A lower risk of developing MetS in the } \\
\text { second, third, and highest quintiles of Mn } \\
\text { intake with respect to the lowest quintile } \\
\text { after adjusting age, sex, and energy intake. }\end{array}$ \\
\hline & & & & & $\begin{array}{l}\text { MetS } \\
\text { components }\end{array}$ & $\begin{array}{l}\text { Daily intake of Mn was decreased with the } \\
\text { increasing number of MetS components. }\end{array}$ \\
\hline [5] & Poland & Cross-sectional study & $\begin{array}{l}313 \text { (men aged } \\
50-75 \text { years) }\end{array}$ & $\begin{array}{c}\text { Serum } \\
\text { (Mn level) }\end{array}$ & $\begin{array}{r}\text { Significant pos } \\
\text { circumfere } \\
\mathrm{Mn}-\mathrm{HOI}\end{array}$ & $\begin{array}{l}\text { tive correlations (Mn-BMI, } \mathrm{Mn} \text {-abdominal } \\
\text { nce, Mn-waist-to-hip ratio, } \mathrm{Mn} \text {-insulin, } \\
\text { MA-IR), but no correlation with MetS. }\end{array}$ \\
\hline \multirow{2}{*}{ [33] } & \multirow{2}{*}{ Korea } & \multirow{2}{*}{$\begin{array}{c}\text { The Korea National } \\
\text { Health and Nutrition } \\
\text { Examination Survey } \\
\text { (2008) }\end{array}$} & \multirow{2}{*}{1405} & $\begin{array}{l}\text { Whole blood } \\
\text { (Mn level) }\end{array}$ & & No difference \\
\hline & & & & $\begin{array}{c}\text { Urine } \\
\text { (Mn level) }\end{array}$ & & No difference \\
\hline
\end{tabular}

transgenic mice that overexpress MnSOD showed protection against diabetic complications, for example, diabetic cardiomyopathy [41], retinopathy [42, 43], and neuropathy [44], while also improving the viability of islet cell transplantation [45]. Therefore, it is very important to maintain the normal function of mitochondrial oxidative stress to prevent the development of T2DM and insulin resistance.

In a study on Zucker rats, a higher mean plasma Mn level in the diabetic fatty group was related to enhanced oxidative stress in diabetes and obesity [46]. Researchers have shown that $\mathrm{Mn}$ treatment can increase insulin secretion to improve glucose tolerance under conditions of dietary stress [47], reduce oxidative stress (ROS) and NADPH oxidase [48], and lower the risk of endothelial dysfunction in diabetes $[48,49]$. A study on nonobese diabetic mice also found that Mn porphyrin catalytic antioxidant $(\mathrm{MnP})$ treatment slightly enhanced glucose oxidation and reduced fatty acid oxidation [50]. Not only dietary Mn deficiency but also acute $\mathrm{Mn}$ exposure in rats can cause decreased plasma insulin levels, rapid hyperglycemia, and hypoinsulinemia, followed by a reactionary hypoglycemia, supporting evidences that the effects of Mn on carbohydrate metabolism may be due to a direct effect on insulin release and gluconeogenesis [51, 52]. A biochemical assessment in male rats' plasma samples showed that $\mathrm{MnO}_{2}$ micro- and nanoparticles after injection of subchronic doses significantly increased plasma glucose and cholesterol levels [53].
Several epidemiologic studies have reported direct associations between Mn level and T2DM, although it remains unclear whether $\mathrm{Mn}$ plays a positive or negative role (Table 2). Current research suggests that the blood Mn level is significantly increased in T2DM patients [54, 55], while some showed decreased levels [3, 56-59] or even no difference in Mn levels compared to the controls [60]. A case-control study of 3228 participants in China indicated a U-shaped association between plasma $\mathrm{Mn}$ and T2DM, with both low and high levels of plasma Mn associated with higher odds of newly diagnosed T2DM [61]. Some research has found a positive correlation between urinary Mn level and T2DM [56, 59]. However, urinary Mn levels of coke oven workers were associated with hyperglycemia risk but not with diabetes risk, which might be due to the small sample size of diabetes and the relatively young population; researchers also found that the concentrations of urinary $\mathrm{Mn}$ in the occupational population were higher than those in the general population [62, 63]. Moreover, results were inconsistent in some studies concerning the Mn concentration in the samples of scalp hair, tears, and lymphocytes among individuals with T2DM $[56,59,64-66]$.

\section{Mn and Obesity}

Over the last several decades, obesity, defined as excessive fat accumulation, has become an increasingly prevalent 
TABLE 2: The epidemiologic studies of Mn level in T2DM, obesity, and atherosclerosis.

\begin{tabular}{|c|c|c|c|c|c|c|}
\hline Reference & Country & Disease & Study design & Sample size & Sample type & Results of Mn level in cases \\
\hline [3] & Korean & T2DM & Cross-sectional study & 3996 & Whole blood & Decreased \\
\hline [54] & Mexico & $\mathrm{T} 2 \mathrm{DM}$ & Cross-sectional study & 76 & Serum & Increased \\
\hline$[34]$ & HIEXICO & $12 \mathrm{NVI}$ & Cinss-sectional stuay & 70 & Urine & No different \\
\hline [55] & Turkey & $\mathrm{T} 2 \mathrm{DM}$ & $\begin{array}{l}\text { Hospital-based } \\
\text { case-control study }\end{array}$ & $\begin{array}{l}\text { Cases: } 200 \\
\text { Controls: } 50\end{array}$ & Serum & Increased \\
\hline$[56]$ & Pakistan & $\mathrm{T} 2 \mathrm{DM}$ & Cross-sectional study & $\begin{array}{l}\text { Diabetes: } 257 \\
\text { Healthy: } 166\end{array}$ & $\begin{array}{l}\text { Whole blood } \\
\text { Urine } \\
\text { Scalp hair }\end{array}$ & $\begin{array}{l}\text { Decreased } \\
\text { Increased } \\
\text { Decreased }\end{array}$ \\
\hline [57] & Egypt & $\mathrm{T} 2 \mathrm{DM}$ & $\begin{array}{l}\text { Hospital-based } \\
\text { case-control study }\end{array}$ & $\begin{array}{l}\text { Cases: } 40 \\
\text { Controls: } 36\end{array}$ & Serum & Decreased \\
\hline [58] & Italy & $\mathrm{T} 2 \mathrm{DM}$ & Case-control study & $\begin{array}{l}\text { Cases: } 68 \\
\text { Controls: } 59\end{array}$ & Whole blood & Decreased \\
\hline [59] & Pakistan & T2DM & $\begin{array}{l}\text { Hospital-based } \\
\text { case-control study }\end{array}$ & $\begin{array}{l}\text { Cases with their } \\
\text { infants: } 76 \\
\text { Healthy with their } \\
\text { infants: } 68\end{array}$ & $\begin{array}{l}\text { Whole blood } \\
\text { Urine } \\
\text { Scalp hair }\end{array}$ & $\begin{array}{l}\text { Decreased } \\
\text { Increased } \\
\text { Decreased }\end{array}$ \\
\hline [60] & $\begin{array}{l}\text { Czech } \\
\text { Republic }\end{array}$ & $\mathrm{T} 2 \mathrm{DM}$ & Cross-sectional study & $\begin{array}{c}1069 \\
\text { (aged 61-100 years) }\end{array}$ & Whole blood & No different \\
\hline [61] & China & $\mathrm{T} 2 \mathrm{DM}$ & Case-control study & $\begin{array}{l}\text { Cases: } 1614 \\
\text { Controls: } 1614\end{array}$ & Plasma & U-shaped association \\
\hline [62] & China & $\mathrm{T} 2 \mathrm{DM}$ & Cross-sectional study & $\begin{array}{c}1493 \\
\text { (coke oven workers) }\end{array}$ & Urine & $\begin{array}{c}\text { Increased association with } \\
\text { hyperglycemia risk but not with } \\
\text { diabetes risk }\end{array}$ \\
\hline [64] & $\begin{array}{l}\text { Pakistan, } \\
\text { Ireland }\end{array}$ & $\mathrm{T} 2 \mathrm{DM}$ & Case-control study & $\begin{array}{l}\text { Cases: } 145 \\
\text { Controls: } 177\end{array}$ & Scalp hair & Decreased \\
\hline [65] & Austria & $\mathrm{T} 2 \mathrm{DM}$ & $\begin{array}{l}\text { Hospital-based } \\
\text { case-control study }\end{array}$ & $\begin{array}{l}\text { Cases: } 53 \\
\text { Controls: } 50\end{array}$ & Lymphocyte & Decreased \\
\hline [66] & Italy & T2DM & Case-control study & $\begin{array}{l}\text { Cases: } 47 \\
\text { Controls: } 50\end{array}$ & Tear & Increased \\
\hline [5] & Poland & Obesity & Cross-sectional study & $\begin{array}{l}313 \text { (men aged } \\
50-75 \text { years) }\end{array}$ & Serum & Increased \\
\hline [83] & Spain & Obesity & Cross-sectional study & 340 & Plasma & $\begin{array}{l}\text { Increased association with the } \\
\text { consumption of dairy products }\end{array}$ \\
\hline [30] & China & Obesity & Cross-sectional study & 2111 & None & $\begin{array}{c}\text { Higher Mn intake (e.g., }>5.12 \mathrm{mg} / \mathrm{d}) \\
\text { was associated with a reduced risk } \\
\text { of abdominal obesity and } \\
\text { hypertriacylglycerolaemia among } \\
\text { men. }\end{array}$ \\
\hline [84] & Turkey & Obesity & $\begin{array}{l}\text { Hospital-based } \\
\text { case-control study }\end{array}$ & $\begin{array}{l}\text { Cases: } 57 \\
\text { Controls: } 48 \\
\text { (children aged } \\
6-17 \text { years) }\end{array}$ & Serum & Increased \\
\hline [85] & Turkey & Obesity & $\begin{array}{c}\text { Prospective } \\
\text { observational study }\end{array}$ & $\begin{array}{l}\text { Cases: } 34 \\
\text { Controls: } 33 \\
\text { (children) }\end{array}$ & Serum & No different \\
\hline [86] & USA & Obesity & Cross-sectional study & $\begin{array}{l}5404 \text { (children } \\
\text { and adolescents } \\
\text { aged } 6-19 \text { years) }\end{array}$ & Serum & Increased \\
\hline [60] & $\begin{array}{l}\text { Czech } \\
\text { Republic }\end{array}$ & Atherosclerosis & Cross-sectional study & $\begin{array}{c}1069 \\
\text { (aged 61-100 years) }\end{array}$ & Whole blood & Increased \\
\hline [102] & Pakistan & Atherosclerosis & Case-control study & $\begin{array}{c}\text { Cases: } 90 \\
\text { Controls: } 90 \\
\text { (aged } 30-62 \text { years) }\end{array}$ & Blood & Increased \\
\hline
\end{tabular}


metabolic disease $[67,68]$ that is associated with increased risk of developing T2DM, cardiovascular disease, and NAFLD. Oxidative stress and production of ROS have been linked to the development of insulin resistance, T2DM, and obesity $[7,8,69]$, suggesting a potential role for ROS in the pathogenesis of these disorders. In mouse 3T3-L1 mature adipocytes, there is an increased generation of superoxide and higher expression of antioxidant enzymes, potentially to help balance cellular ROS $[70,71]$. In the presence of high ROS production, the antioxidant capacity of adipose tissue is also impaired in mouse models of obesity, and antioxidants such as SOD mimetics exert beneficial effects in metabolic diseases associated with obesity [72-75].

Compared with those fed a normal diet, rats fed a high fat-cholesterol diet had a significant decrease in MnSOD activity [76]. It has been shown that MnSOD deletion in mouse adipocytes triggers an adaptive stress response that activates mitochondrial biogenesis and enhanced mitochondrial fatty acid oxidation, thereby preventing diet-induced obesity and insulin resistance [77]. On the other hand, inflammation and excess triglyceride storage induced in obesity mice would raise epididymal adipocyte MnSOD [78]. In mouse studies, manganese [III] tetrakis [5,10,15,20]-benzoic acid porphyrin (MnTBAP), a nonpeptidic mimic of MnSOD, significantly reduced excess body weight and serum superoxide anion generation [79], ameliorated preexisting obesity, and improved insulin action by reducing caloric intake [80]. However, regarding the effect of MnTBAP on adiposity mice and in vivo insulin action, the evidences were conflicting. One suggested a preventive effect on the development of systemic insulin resistance and diabetes after high-fat diet, while the other was not $[75,81]$.

The concentrations of $\mathrm{Mn}$ in the liver, small intestine, and bone of obese mice were significantly lower than those in lean mice [82]. The cross-sectional epidemiological survey has found that plasma Mn was directly correlated with the consumption of dairy products [83]. Higher Mn intake (e.g., $>5.12 \mathrm{mg} / \mathrm{d}$ ) was associated with reduced risk of abdominal obesity and hypertriacylglycerolaemia among men in China [30]. Poland researchers have found that plasma Mn concentration was significantly higher in obese men aged 50-75 years [5]. Nevertheless, the data about blood Mn level in obese children are not consistent [84, 85]. The US National Health and Nutrition Examination Survey 20112014, performed with 5404 children and adolescents aged 6-19 years, revealed that the highest blood Mn concentration was associated with obesity and overweight [86].

\section{Mn and Atherosclerosis}

Atherosclerosis is the disease of the arterial wall, characterized by cholesterol accumulation, and culminates in potentially life-threatening conditions, such as heart attack, stroke, and angina [87]. Recent evidence suggests that atherosclerosis is a chronic inflammatory disease of the blood vessel wall [88-90]. Oxidized low-density lipoprotein (oxLDL) and endothelium dysfunction play a key role in the pathogenesis of atherosclerosis [91, 92]. Accumulation of oxLDL in the arterial wall is a characteristic feature of disease progression [88].

Previous studies have demonstrated that the roles of oxLDL and endothelium dysfunction are closely related to the imbalance of oxidative stress and inflammation in the pathogenic process of atherosclerosis [9, 10, 93, 94]. Mitochondrial DNA damage may result from reactive species production in vascular tissues and may in turn be an early event in the initiation of atherosclerotic lesions [95]. MnSOD was reported to reduce the oxLDL-induced apoptosis of macrophages $[87,96]$, protect against endothelial dysfunction $[97,98]$, and inhibit the oxidation of LDL by endothelial cells [9]. Furthermore, the association of decreased activity of MnSOD with atherogenesis has suggested that analysis of Mn content in the vascular wall matrix may be one of prospective methods for the diagnosis of early stages of atherosclerosis [99].

Several studies indicated that Mn supplementation could reduce high glucose-induced monocyte adhesion to endothelial cells and endothelial dysfunction and also lower blood levels of ICAM-1 and cholesterol [48, 49], elicit anti-inflammatory effects in endothelial cells [100], and potentially prevent or delay the progression of atherosclerosis. Little is known about the Mn concentration in atherosclerosis patient samples. It has been observed that the difference between the Mn contents of normal and atherosclerotic aortic tissue was not significant [101]. However, in epidemiologic studies, higher blood Mn levels were found in senior citizens aged 61-100 years with atherosclerosis compared to those without [60]. The same result was found in individuals aged $30-62$ years [102].

\section{Mn and Nonalcoholic Fatty Liver Disease}

NAFLD, characterized by excess triglyceride (TG) accumulation in the absence of excessive alcohol intake, is the most common chronic liver disease and associated with MetS, obesity, and T2DM [103, 104]. This disease can progress to inflammatory nonalcoholic steatohepatitis (NASH), fibrosis, cirrhosis, and end-stage liver injury in humans [105, 106]. $\mathrm{NASH}$, defined as a necroinflammatory disorder with fatty infiltration of hepatocytes, may progress to fibrosis and lead to cirrhosis [105]. Moreover, nonalcoholic steatosis is the first step in the pathogenesis of NASH linked to mitochondrial dysfunction and oxidative stress [11, 12, 107-109]. Rat histopathological observations suggest that nonpeptidyl mimics of MnSOD may help in the prevention and treatment of NASH in humans [79, 110]. However, few researchers have focused on the association between Mn concentration and NAFLD. In an in vitro NAFLD model established in human SMMC-7721 cells, Mn concentration did not significantly change in oleic acid-induced hepatic steatosis cells compared to the control [111].

\section{Conclusions}

Metabolic diseases are affected by dietary habits, the environment, and genes independently and through their interactions. They are complex diseases caused by multiple etiologies. 
Intracellular homeostasis of $\mathrm{Mn}$ is associated with some metals. The Mn concentration also affects the absorption and metabolism of other metals. For example, Mn competes for iron $(\mathrm{Fe})$ transporters by inhibiting divalent metal transporter 1 (DMT1) binding with Fe and disrupting the homeostasis of cesium (Cs), cobalt $(\mathrm{Co})$, lead $(\mathrm{Pb})$, mercury $(\mathrm{Hg})$, nickel $(\mathrm{Ni})$, and zinc $(\mathrm{Zn})$ in cells [112]. Researchers have found that $\mathrm{Fe}$ depletion increases uptake and potentiates Mn-induced apoptosis, indicated by increased terminal deoxynucleotidyl transferase-mediated dUTP nick end labeling (TUNEL) staining of rat olfactory bulb and human SHSY5Y cells [113]. Thus, low Fe levels could result in greater absorbance and accumulation of $\mathrm{Mn}$, further influencing its toxicity $[114,115]$. Moreover, $\mathrm{Mn}$, copper $(\mathrm{Cu})$, and $\mathrm{Zn}$ also competitively combined with SOD in oxidative stress. Alternatively, $\mathrm{Mn}$ exposure leads to increased $\mathrm{Cu}$ levels and decreased $\mathrm{Fe}$ and $\mathrm{Ca}$ levels in Caenorhabditis elegans (C. elegans) [116]. Therefore, studies about mixtures of metals are needed to better clarify how they crosstalk in metabolic diseases.

MnSOD plays a key role in mitochondrial oxidative stress, while the MnSOD Val16Ala polymorphism (rs4880) could result in reduced MnSOD activity and less efficient transport of MnSOD into the mitochondrial matrix $[117,118]$. Both the MnSOD gene and levels of Mn could affect the activity of MnSOD [119]. Moreover, Mn supplementation enhanced MnSOD activity and protected against T2DM and its complications [47, 49]. Consequently, it is very important to systematically analyze whether the association with the risk of metabolic diseases and Mn levels is modified by genetic variation in $\mathrm{MnSOD}, \mathrm{Cu} / \mathrm{ZnSOD}$, and related genes associated with $\mathrm{Mn}$ uptake, transport, metabolism, and excretion, such as DMT1, transferrin receptor (TfR), and soluble carrier family (SLC).

Several vitamins are antioxidative compounds, for example, vitamin $\mathrm{C}$, vitamin $\mathrm{D} 3$, vitamin $\mathrm{E}$, and $\beta$-carotene. The human-derived Caco-2 cell study indicated that expression of the SLC30A10 gene, as well as its encoded protein, the $\mathrm{Zn}$ and $\mathrm{Mn}$ transporter ZnT10, was augmented by vitamin D3 treatment [120]. MnSOD activity was significantly increased with high doses (30 and $100 \mathrm{mg} / \mathrm{kg}$ ) of vitamin $\mathrm{E}$ after 4 and 6 weeks [121]. Thus, it is worth considering whether there is a causal relationship between Mn level and vitamin levels in the process of oxidation.

Previous researches have had small sample sizes, were designed primarily as cross-sectional and case-control studies, and lack large sample prospective studies. Therefore, a cohort study is urgently needed to confirm the causality between $\mathrm{Mn}$ and metabolic diseases, especially in occupational Mn-exposed workers [122]. In addition, by using a biological model study, for example, zebrafish and C. elegans $[123,124]$, we can further verify the effects of $\mathrm{Mn}$ and the combined action of various metals on metabolic diseases that were found in previous epidemiologic studies.

In summary, $\mathrm{Mn}$ is both a toxic and an essential trace element involved in human health and development. In the current literature, research supports a view that a U-shaped association exists between $\mathrm{Mn}$, either deficiency in dietary Mn or excessive Mn exposure, and increased ROS generation as well as oxidative stress, which might affect the occurrence of metabolic diseases further, although it remains inadequate in molecular and epidemiological data on disease patients, especially among Mn workers.

\section{Conflicts of Interest}

The authors declare that there is no conflict of interest regarding the publication of this article.

\section{Acknowledgments}

This work was supported by the National Natural Science Foundation of China (Grant no. 81472962), the Fok Ying Tong Education Foundation's Young Teacher Award (Grant no. 141118), and the National Natural Science Foundation of Guangxi (Grant no. 2017GXNSFGA198003).

\section{References}

[1] Q. Deng, J. Liu, Q. Li et al., "Interaction of occupational manganese exposure and alcohol drinking aggravates the increase of liver enzyme concentrations from a crosssectional study in China," Environmental Health, vol. 12, no. 1, p. 30, 2013.

[2] J. L. Aschner and M. Aschner, "Nutritional aspects of manganese homeostasis," Molecular Aspects of Medicine, vol. 26, no. 4-5, pp. 353-362, 2005.

[3] E. S. Koh, S. J. Kim, H. E. Yoon et al., "Association of blood manganese level with diabetes and renal dysfunction: a cross-sectional study of the Korean general population," BMC Endocrine Disorders, vol. 14, no. 1, p. 24, 2014.

[4] R. Stegemann and D. A. Buchner, "Transgenerational inheritance of metabolic disease," Seminars in Cell \& Developmental Biology, vol. 43, pp. 131-140, 2015.

[5] I. Rotter, D. Kosik-Bogacka, B. Dołęgowska, K. Safranow, A. Lubkowska, and M. Laszczyńska, "Relationship between the concentrations of heavy metals and bioelements in aging men with metabolic syndrome," International Journal of Environmental Research and Public Health, vol. 12, no. 12, pp. 3944-3961, 2015.

[6] D. Liu, L. Liu, Z. Hu, Z. Song, Y. Wang, and Z. Chen, "Evaluation of the oxidative stress-related genes ALOX5, $A L O X 5 A P, G P X 1, G P X 3$ and MPO for contribution to the risk of type 2 diabetes mellitus in the Han Chinese population," Diabetes and Vascular Disease Research, 2018.

[7] M. Johns, R. Fyalka, J. A. Shea et al., "SR-135, a peroxynitrite decomposing catalyst, enhances $\beta$-cell function and survival in B6D2F1 mice fed a high fat diet," Archives of Biochemistry and Biophysics, vol. 577-578, pp. 49-59, 2015.

[8] D. S. Fernandez-Twinn and S. E. Ozanne, "Early life nutrition and metabolic programming," Annals of the New York Academy of Sciences, vol. 1212, no. 1, pp. 78-96, 2010.

[9] X. Fang, N. L. Weintraub, C. D. Rios et al., "Overexpression of human superoxide dismutase inhibits oxidation of low-density lipoprotein by endothelial cells," Circulation Research, vol. 82, no. 12, pp. 1289-1297, 1998.

[10] M. Glover, V. Y. Hebert, K. Nichols et al., "Overexpression of mitochondrial antioxidant manganese superoxide dismutase (MnSOD) provides protection against AZT- or 
3TC-induced endothelial dysfunction," Antiviral Research, vol. 111, pp. 136-142, 2014.

[11] B. Fromenty, M. A. Robin, A. Igoudjil, A. Mansouri, and D. Pessayre, "The ins and outs of mitochondrial dysfunction in NASH," Diabetes \& Metabolism, vol. 30, no. 2, pp. 121138, 2004.

[12] K. Mehta, D. H. Van Thiel, N. Shah, and S. Mobarhan, "Nonalcoholic fatty liver disease: pathogenesis and the role of antioxidants," Nutrition Reviews, vol. 60, no. 9, pp. 289293, 2002.

[13] M. Korc, "Manganese action on pancreatic protein synthesis in normal and diabetic rats," American Journal of PhysiologyGastrointestinal and Liver Physiology, vol. 245, no. 5, pp. G628-G634, 1983.

[14] E. Martin-Montañez, J. Pavia, L. J. Santin et al., "Involvement of IGF-II receptors in the antioxidant and neuroprotective effects of IGF-II on adult cortical neuronal cultures," Biochimica et Biophysica Acta (BBA) - Molecular Basis of Disease, vol. 1842, no. 7, pp. 1041-1051, 2014.

[15] S. Munusamy and L. A. MacMillan-Crow, "Mitochondrial superoxide plays a crucial role in the development of mitochondrial dysfunction during high glucose exposure in rat renal proximal tubular cells," Free Radical Biology \& Medicine, vol. 46, no. 8, pp. 1149-1157, 2009.

[16] J. Azadmanesh and G. Borgstahl, "A review of the catalytic mechanism of human manganese superoxide dismutase," Antioxidants, vol. 7, no. 2, 2018.

[17] L. I. Rachek, S. I. Musiyenko, S. P. LeDoux, and G. L. Wilson, "Palmitate induced mitochondrial deoxyribonucleic acid damage and apoptosis in 16 rat skeletal muscle cells," Endocrinology, vol. 148, no. 1, pp. 293-299, 2007.

[18] J. L. Greger, "Nutrition versus toxicology of manganese in humans: evaluation of potential biomarkers," Neurotoxicology, vol. 20, no. 2-3, pp. 205-212, 1999.

[19] "Manganese deficiency in humans: fact or fiction?," Nutrition Reviews, vol. 46, no. 10, pp. 348-352, 1988.

[20] E. A. Malecki, "Manganese toxicity is associated with mitochondrial dysfunction and DNA fragmentation in rat primary striatal neurons," Brain Research Bulletin, vol. 55, no. 2, pp. 225-228, 2001.

[21] K. V. R. Rao and M. D. Norenberg, "Manganese induces the mitochondrial permeability transition in cultured astrocytes," Journal of Biological Chemistry, vol. 279, no. 31, pp. 32333-32338, 2004.

[22] K. Sriram, G. X. Lin, A. M. Jefferson et al., "Mitochondrial dysfunction and loss of Parkinson's disease-linked proteins contribute to neurotoxicity of manganese-containing welding fumes," FASEB Journal, vol. 24, no. 12, pp. 4989-5002, 2010.

[23] Y. X. Zheng, P. Chan, Z. F. Pan et al., "Polymorphism of metabolic genes and susceptibility to occupational chronic manganism," Biomarkers, vol. 7, no. 4, pp. 337-346, 2002.

[24] E. S. Ford, C. Li, L. C. McGuire, A. H. Mokdad, and S. Liu, "Intake of dietary magnesium and the prevalence of the metabolic syndrome among U.S. adults," Obesity, vol. 15, no. 5, pp. 1139-1146, 2007.

[25] M. A. Cornier, D. Dabelea, T. L. Hernandez et al., "The metabolic syndrome," Endocrine Reviews, vol. 29, no. 7, pp. 777-822, 2008.

[26] K. E. Wellen and G. S. Hotamisligil, "Inflammation, stress, and diabetes," Journal of Clinical Investigation, vol. 115, no. 5, pp. 1111-1119, 2005.
[27] S. Furukawa, T. Fujita, M. Shimabukuro et al., "Increased oxidative stress in obesity and its impact on metabolic syndrome," Journal of Clinical Investigation, vol. 114, no. 12, pp. 1752-1761, 2004.

[28] J. F. Keaney Jr., M. G. Larson, R. S. Vasan et al., "Obesity and systemic oxidative stress: clinical correlates of oxidative stress in the Framingham Study," Arteriosclerosis, Thrombosis, and Vascular Biology, vol. 23, no. 3, pp. 434-439, 2003.

[29] M. Pinzani, F. Marra, and V. Carloni, "Signal transduction in hepatic stellate cells," Liver, vol. 18, no. 1, pp. 2-13, 1998.

[30] B. Zhou, X. Su, D. Su et al., "Dietary intake of manganese and the risk of the metabolic syndrome in a Chinese population," British Journal of Nutrition, vol. 116, no. 5, pp. 853-863, 2016.

[31] M. K. Choi and Y. J. Bae, "Relationship between dietary magnesium, manganese, and copper and metabolic syndrome risk in Korean adults: the Korea National Health and Nutrition Examination Survey (2007-2008)," Biological Trace Element Research, vol. 156, no. 1-3, pp. 56-66, 2013.

[32] Y. Li, H. Guo, M. Wu, and M. Liu, "Serum and dietary antioxidant status is associated with lower prevalence of the metabolic syndrome in a study in Shanghai, China," Asia Pacific Journal of Clinical Nutrition, vol. 22, no. 1, pp. 6068, 2013.

[33] S. Y. Rhee, Y. C. Hwang, J. T. Woo et al., "Blood lead is significantly associated with metabolic syndrome in Korean adults: an analysis based on the Korea National Health and Nutrition Examination Survey (KNHANES), 2008," Cardiovascular Diabetology, vol. 12, no. 1, p. 9, 2013.

[34] P. Zimmet, K. G. M. M. Alberti, and J. Shaw, "Global and societal implications of the diabetes epidemic," Nature, vol. 414, no. 6865, pp. 782-787, 2001.

[35] F. Giacco and M. Brownlee, "Oxidative stress and diabetic complications," Circulation Research, vol. 107, no. 9, pp. 1058-1070, 2010.

[36] T. Nishikawa, D. Edelstein, X. L. du et al., "Normalizing mitochondrial superoxide production blocks three pathways of hyperglycaemic damage," Nature, vol. 404, no. 6779, pp. 787-790, 2000.

[37] S. D. Martin, S. Morrison, N. Konstantopoulos, and S. L. McGee, "Mitochondrial dysfunction has divergent, cell type-dependent effects on insulin action," Molecular Metabolism, vol. 3, no. 4, pp. 408-418, 2014.

[38] B. B. Lowell and G. I. Shulman, "Mitochondrial dysfunction and type 2 diabetes," Science, vol. 307, no. 5708, pp. 384387, 2005.

[39] K. Morino, K. F. Petersen, S. Dufour et al., "Reduced mitochondrial density and increased IRS-1 serine phosphorylation in muscle of insulin-resistant offspring of type 2 diabetic parents," Journal of Clinical Investigation, vol. 115, no. 12, pp. 3587-3593, 2005.

[40] K. L. Hoehn, A. B. Salmon, C. Hohnen-Behrens et al., "Insulin resistance is a cellular antioxidant defense mechanism," Proceedings of the National Academy of Sciences of the United States of America, vol. 106, no. 42, pp. 17787-17792, 2009.

[41] X. Shen, S. Zheng, N. S. Metreveli, and P. N. Epstein, "Protection of cardiac mitochondria by overexpression of MnSOD reduces diabetic cardiomyopathy," Diabetes, vol. 55, no. 3, pp. 798-805, 2006.

[42] H. Goto, T. Nishikawa, K. Sonoda et al., "Endothelial MnSOD overexpression prevents retinal VEGF expression 
in diabetic mice," Biochemical and Biophysical Research Communications, vol. 366, no. 3, pp. 814-820, 2008.

[43] R. A. Kowluru, V. Kowluru, Y. Xiong, and Y. S. Ho, “Overexpression of mitochondrial superoxide dismutase in mice protects the retina from diabetes-induced oxidative stress," Free Radical Biology \& Medicine, vol. 41, no. 8, pp. 11911196, 2006.

[44] A. M. Vincent, J. W. Russell, K. A. Sullivan et al., "SOD2 protects neurons from injury in cell culture and animal models of diabetic neuropathy," Experimental Neurology, vol. 208, no. 2, pp. 216-227, 2007.

[45] S. Bertera, M. L. Crawford, A. M. Alexander et al., "Gene transfer of manganese superoxide dismutase extends islet graft function in a mouse model of autoimmune diabetes," Diabetes, vol. 52, no. 2, pp. 387-393, 2003.

[46] M. Navarro-Alarcon, F. J. Ruiz-Ojeda, R. M. Blanca-Herrera, and A. Agil, "Antioxidant activity of melatonin in diabetes in relation to the regulation and levels of plasma $\mathrm{Cu}, \mathrm{Zn}, \mathrm{Fe}, \mathrm{Mn}$, and Se in Zucker diabetic fatty rats," Nutrition, vol. 29, no. 5, pp. 785-789, 2013.

[47] S. H. Lee, H. A. Jouihan, R. C. Cooksey et al., "Manganese supplementation protects against diet-induced diabetes in wild type mice by enhancing insulin secretion," Endocrinology, vol. 154, no. 3, pp. 1029-1038, 2013.

[48] E. Burlet and S. K. Jain, "Manganese supplementation increases adiponectin and lowers ICAM-1 and creatinine blood levels in Zucker type 2 diabetic rats, and downregulates ICAM-1 by upregulating adiponectin multimerization protein (DsbA-L) in endothelial cells," Molecular and Cellular Biochemistry, vol. 429, no. 1-2, pp. 1-10, 2017.

[49] E. Burlet and S. K. Jain, "Manganese supplementation reduces high glucose-induced monocyte adhesion to endothelial cells and endothelial dysfunction in Zucker diabetic fatty rats," Journal of Biological Chemistry, vol. 288, no. 9, pp. 6409-6416, 2013.

[50] M. M. Delmastro-Greenwood, T. Votyakova, E. Goetzman et al., "Mn porphyrin regulation of aerobic glycolysis: implications on the activation of diabetogenic immune cells," Antioxidants \& Redox Signaling, vol. 19, no. 16, pp. 19021915, 2013.

[51] D. Baly, B. Lonnerdal, and C. Keen, "Effects of high doses of manganese on carbohydrate homeostasis," Toxicology Letters, vol. 25, no. 1, pp. 95-102, 1985.

[52] L. S. Hurley, C. L. Keen, and D. L. Baly, "Manganese deficiency and toxicity: effects on carbohydrate metabolism in the rat," Neurotoxicology, vol. 5, no. 1, pp. 97-104, 1984.

[53] Z. Mousavi, M. Hassanpourezatti, P. Najafizadeh, S. Rezagholian, M. S. Rhamanifar, and N. Nosrati, "Effects of subcutaneous injection $\mathrm{MnO}_{2}$ micro- and nanoparticles on blood glucose level and lipid profile in rat," Iranian Journal of Medical Sciences, vol. 41, no. 6, pp. 518-524, 2016.

[54] C. R. Flores, M. P. Puga, K. Wrobel, M. E. Garay Sevilla, and K. Wrobel, "Trace elements status in diabetes mellitus type 2: possible role of the interaction between molybdenum and copper in the progress of typical complications," Diabetes Research and Clinical Practice, vol. 91, no. 3, pp. 333-341, 2011.

[55] S. Ekin, N. Mert, H. Gunduz, and I. Meral, "Serum sialic acid levels and selected mineral status in patients with type 2 diabetes mellitus," Biological Trace Element Research, vol. 94, no. 3, pp. 193-202, 2003.
[56] T. G. Kazi, H. I. Afridi, N. Kazi et al., "Copper, chromium, manganese, iron, nickel, and zinc levels in biological samples of diabetes mellitus patients," Biological Trace Element Research, vol. 122, no. 1, pp. 1-18, 2008.

[57] M. Badran, R. Morsy, H. Soliman, and T. Elnimr, "Assessment of trace elements levels in patients with type 2 diabetes using multivariate statistical analysis," Journal of Trace Elements in Medicine and Biology, vol. 33, pp. 114119, 2016.

[58] G. Forte, B. Bocca, A. Peruzzu et al., "Blood metals concentration in type 1 and type 2 diabetics," Biological Trace Element Research, vol. 156, no. 1-3, pp. 79-90, 2013.

[59] H. I. Afridi, T. G. Kazi, N. Kazi et al., "Status of essential trace metals in biological samples of diabetic mother and their neonates," Archives of Gynecology and Obstetrics, vol. 280, no. 3, pp. 415-423, 2009.

[60] J. Rambousková, A. Krsková, M. Slavíková et al., “Trace elements in the blood of institutionalized elderly in the Czech Republic," Archives of Gerontology and Geriatrics, vol. 56, no. 2, pp. 389-394, 2013.

[61] Z. Shan, S. Chen, T. Sun et al., "U-shaped association between plasma manganese levels and type 2 diabetes," Environmental Health Perspectives, vol. 124, no. 12, pp. 18761881, 2016.

[62] B. Liu, W. Feng, J. Wang et al., "Association of urinary metals levels with type 2 diabetes risk in coke oven workers," Environmental Pollution, vol. 210, pp. 1-8, 2016.

[63] W. Feng, X. He, M. Chen et al., "Urinary metals and heart rate variability: a cross-sectional study of urban adults in Wuhan, China," Environmental Health Perspectives, vol. 123, no. 3, pp. 217-222, 2015.

[64] H. I. Afridi, T. G. Kazi, D. Brabazon, S. Naher, and F. N. Talpur, "Comparative metal distribution in scalp hair of Pakistani and Irish referents and diabetes mellitus patients," Clinica Chimica Acta, vol. 415, pp. 207-214, 2013.

[65] C. Ekmekcioglu, C. Prohaska, K. Pomazal, I. Steffan, G. Schernthaner, and W. Marktl, "Concentrations of seven trace elements in different hematological matrices in patients with type 2 diabetes as compared to healthy controls," Biological Trace Element Research, vol. 79, no. 3, pp. 205-219, 2001.

[66] A. Cancarini, J. Fostinelli, L. Napoli, M. E. Gilberti, P. Apostoli, and F. Semeraro, "Trace elements and diabetes: assessment of levels in tears and serum," Experimental Eye Research, vol. 154, pp. 47-52, 2017.

[67] C. L. Ogden, M. D. Carroll, and K. M. Flegal, "Prevalence of obesity in the United States," JAMA, vol. 312, no. 2, pp. 189-190, 2014.

[68] C. P. Kovesdy, S. L. Furth, C. Zoccali, and on behalf of the World Kidney Day Steering Committee, "Obesity and kidney disease: hidden consequences of the epidemic," American Journal of Nephrology, vol. 45, no. 3, pp. 283-291, 2017.

[69] N. Bashan, J. Kovsan, I. Kachko, H. Ovadia, and A. Rudich, "Positive and negative regulation of insulin signaling by reactive oxygen and nitrogen species," Physiological Reviews, vol. 89, no. 1, pp. 27-71, 2009.

[70] P. H. Ducluzeau, M. Priou, M. Weitheimer et al., "Dynamic regulation of mitochondrial network and oxidative functions during 3T3-L1 fat cell differentiation," Journal of Physiology and Biochemistry, vol. 67, no. 3, pp. 285-296, 2011. 
[71] T. Kojima, T. Norose, K. Tsuchiya, and K. Sakamoto, "Mouse 3T3-L1 cells acquire resistance against oxidative stress as the adipocytes differentiate via the transcription factor FoxO," Apoptosis, vol. 15, no. 1, pp. 83-93, 2010.

[72] A. R. Subauste and C. F. Burant, "Role of FoxO1 in FFAinduced oxidative stress in adipocytes," American Journal of Physiology-Endocrinology and Metabolism, vol. 293, no. 1, pp. E159-E164, 2007.

[73] H. Kobayashi, M. Matsuda, A. Fukuhara, R. Komuro, and I. Shimomura, "Dysregulated glutathione metabolism links to impaired insulin action in adipocytes," American Journal of Physiology-Endocrinology and Metabolism, vol. 296, no. 6, pp. E1326-E1334, 2009.

[74] K. C. Coate and K. W. Huggins, "Consumption of a high glycemic index diet increases abdominal adiposity but does not influence adipose tissue pro-oxidant and antioxidant gene expression in C57BL/6 mice," Nutrition Research, vol. 30, no. 2, pp. 141-150, 2010.

[75] K. M. Pires, O. Ilkun, M. Valente, and S. Boudina, "Treatment with a SOD mimetic reduces visceral adiposity, adipocyte death, and adipose tissue inflammation in high fat-fed mice," Obesity, vol. 22, no. 1, pp. 178-187, 2014.

[76] S. H. Ko, J. H. Park, S. Y. Kim, S. W. Lee, S. S. Chun, and E. Park, "Antioxidant effects of spinach (Spinacia oleracea L.) supplementation in hyperlipidemic rats," Preventive Nutrition and Food Science, vol. 19, no. 1, pp. 19-26, 2014.

[77] Y. H. Han, M. Buffolo, K. M. Pires, S. Pei, P. E. Scherer, and S. Boudina, "Adipocyte-specific deletion of manganese superoxide dismutase protects from diet-induced obesity through increased mitochondrial uncoupling and biogenesis," Diabetes, vol. 65, no. 9, pp. 2639-2651, 2016.

[78] S. Krautbauer, K. Eisinger, M. Neumeier et al., "Free fatty acids, lipopolysaccharide and IL- $1 \alpha$ induce adipocyte manganese superoxide dismutase which is increased in visceral adipose tissues of obese rodents," PLoS One, vol. 9, no. 1, article e86866, 2014.

[79] A. Laurent, C. Nicco, J. Tran van Nhieu et al., "Pivotal role of superoxide anion and beneficial effect of antioxidant molecules in murine steatohepatitis," Hepatology, vol. 39, no. 5, pp. 1277-1285, 2004.

[80] J. R. Brestoff, T. Brodsky, A. Z. Sosinsky et al., "Manganese [III] tetrakis $[5,10,15,20]$-benzoic acid porphyrin reduces adiposity and improves insulin action in mice with pre-existing obesity," PLoS One, vol. 10, no. 9, article e0137388, 2015.

[81] N. Houstis, E. D. Rosen, and E. S. Lander, "Reactive oxygen species have a causal role in multiple forms of insulin resistance," Nature, vol. 440, no. 7086, pp. 944-948, 2006.

[82] M. L. Kennedy, M. L. Failla, and J. C. Smith Jr., "Influence of genetic obesity on tissue concentrations of zinc, copper, manganese and iron in mice," Journal of Nutrition, vol. 116, no. 8, pp. 1432-1441, 1986.

[83] C. Sanchez, M. Lopez-Jurado, P. Aranda, and J. Llopis, "Plasma levels of copper, manganese and selenium in an adult population in southern Spain: influence of age, obesity and lifestyle factors," Science of the Total Environment, vol. 408, no. 5, pp. 1014-1020, 2010.

[84] Y. Cayir, A. Cayir, M. I. Turan et al., "Antioxidant status in blood of obese children: the relation between trace elements, paraoxonase, and arylesterase values," Biological Trace Element Research, vol. 160, no. 2, pp. 155-160, 2014.
[85] M. E. Tascilar, I. T. Ozgen, A. Abaci, M. Serdar, and O. Aykut, "Trace elements in obese Turkish children," Biological Trace Element Research, vol. 143, no. 1, pp. 188-195, 2011.

[86] Y. Fan, C. Zhang, and J. Bu, "Relationship between selected serum metallic elements and obesity in children and adolescent in the U.S.," Nutrients, vol. 9, no. 12, 2017.

[87] V. A. Shatrov and B. Brune, "Induced expression of manganese superoxide dismutase by non-toxic concentrations of oxidized low-density lipoprotein (oxLDL) protects against oxLDL-mediated cytotoxicity," Biochemical Journal, vol. 374, no. 2, pp. 505-511, 2003.

[88] R. Ross, "Atherosclerosis-an inflammatory disease," New England Journal of Medicine, vol. 340, no. 2, pp. 115126, 1999.

[89] A. J. Lusis, “Atherosclerosis," Nature, vol. 407, no. 6801, pp. 233-241, 2000.

[90] L. Hegyi, S. J. Hardwick, R. C. M. Siow, and J. N. Skepper, "Macrophage death and the role of apoptosis in human atherosclerosis," Journal of Hematotherapy \& Stem Cell Research, vol. 10, no. 1, pp. 27-42, 2001.

[91] D. P. Hajjar and M. E. Haberland, "Lipoprotein trafficking in vascular cells. Molecular Trojan horses and cellular saboteurs," Journal of Biological Chemistry, vol. 272, no. 37, pp. 22975-22978, 1997.

[92] J. W. Heinecke, "Oxidants and antioxidants in the pathogenesis of atherosclerosis: implications for the oxidized low density lipoprotein hypothesis," Atherosclerosis, vol. 141, no. 1, pp. 1-15, 1998.

[93] J. Steppan, D. Nyhan, and D. E. Berkowitz, "Development of novel arginase inhibitors for therapy of endothelial dysfunction," Frontiers in Immunology, vol. 4, p. 278, 2013.

[94] M. Feletou and P. M. Vanhoutte, "Endothelial dysfunction: a multifaceted disorder (The Wiggers Award Lecture)," American Journal of Physiology-Heart and Circulatory Physiology, vol. 291, no. 3, pp. H985-H1002, 2006.

[95] S. W. Ballinger, C. Patterson, C. A. Knight-Lozano et al., "Mitochondrial integrity and function in atherogenesis," Circulation, vol. 106, no. 5, pp. 544-549, 2002.

[96] R. Kinscherf, R. Claus, M. Wagner et al., “Apoptosis caused by oxidized LDL is manganese superoxide dismutase and p53 dependent," FASEB Journal, vol. 12, no. 6, pp. 461467, 1998.

[97] F. Jiang, Y. Guo, D. Salvemini, and G. J. Dusting, "Superoxide dismutase mimetic M40403 improves endothelial function in apolipoprotein(E)-deficient mice," British Journal of Pharmacology, vol. 139, no. 6, pp. 1127-1134, 2003.

[98] M. Ohashi, M. S. Runge, F. M. Faraci, and D. D. Heistad, "MnSOD deficiency increases endothelial dysfunction in ApoE-deficient mice," Arteriosclerosis, Thrombosis, and Vascular Biology, vol. 26, no. 10, pp. 2331-2336, 2006.

[99] A. P. Lozhkin, T. B. Biktagirov, V. A. Abdul'yanov et al., "Manganese in atherogenesis: detection, origin, and a role," Biochemistry (Moscow) Supplement Series B: Biomedical Chemistry, vol. 5, no. 2, pp. 158-162, 2011.

[100] Q. Zhou, M. Einert, H. Schmitt et al., "MnTBAP increases BMPR-II expression in endothelial cells and attenuates vascular inflammation," Vascular Pharmacology, vol. 84, pp. 67-73, 2016.

[101] S. Mendis, "Magnesium, zinc, and manganese in atherosclerosis of the aorta," Biological Trace Element Research, vol. 22, no. 3, pp. 251-256, 1989. 
[102] A. Ilyas and M. H. Shah, "Multivariate statistical evaluation of trace metal levels in the blood of atherosclerosis patients in comparison with healthy subjects," Heliyon, vol. 2, no. 1, article e00054, 2016.

[103] K. Cusi, "Role of insulin resistance and lipotoxicity in nonalcoholic steatohepatitis," Clinics in Liver Disease, vol. 13, no. 4, pp. 545-563, 2009.

[104] E. Fabbrini, S. Sullivan, and S. Klein, "Obesity and nonalcoholic fatty liver disease: biochemical, metabolic, and clinical implications," Hepatology, vol. 51, no. 2, pp. 679-689, 2010.

[105] P. Angulo, "Nonalcoholic fatty liver disease," New England Journal of Medicine, vol. 346, no. 16, pp. 1221-1231, 2002.

[106] A. E. Feldstein, A. Canbay, M. E. Guicciardi, H. Higuchi, S. F. Bronk, and G. J. Gores, "Diet associated hepatic steatosis sensitizes to Fas mediated liver injury in mice," Journal of Hepatology, vol. 39, no. 6, pp. 978-983, 2003.

[107] D. Pessayre, A. Mansouri, and B. Fromenty, "V. Mitochondrial dysfunction in steatohepatitis," American Journal of Physiology-Gastrointestinal and Liver Physiology, vol. 282, no. 2, pp. G193-G199, 2002.

[108] H. Jaeschke, G. J. Gores, A. I. Cederbaum, J. A. Hinson, D. Pessayre, and J. J. Lemasters, "Mechanisms of hepatotoxicity,” Toxicological Sciences, vol. 65, no. 2, pp. 166-176, 2002.

[109] S. Chitturi and G. C. Farrell, "Etiopathogenesis of nonalcoholic steatohepatitis," Seminars in Liver Disease, vol. 21, no. 1, pp. 27-42, 2001.

[110] A. Rezazadeh and R. Yazdanparast, "Prevention of nonalcoholic steatohepatitis in rats by two manganese-salen complexes," Iranian Biomedical Journal, vol. 18, no. 1, pp. 41-48, 2014.

[111] S. Wang, X. Kuang, Z. Fang, Z. Huang, and P. Shi, "Effect of oleic acid on the levels of eight metal ions in human hepatoma SMMC-7721 cells," Biological Trace Element Research, vol. 159, no. 1-3, pp. 445-450, 2014.

[112] P. Chen, S. Chakraborty, S. Mukhopadhyay et al., "Manganese homeostasis in the nervous system," Journal of Neurochemistry, vol. 134, no. 4, pp. 601-610, 2015.

[113] Y. A. Seo, Y. Li, and M. Wessling-Resnick, "Iron depletion increases manganese uptake and potentiates apoptosis through ER stress," NeuroToxicology, vol. 38, pp. 67-73, 2013.

[114] V. A. Fitsanakis, N. Zhang, M. J. Avison, K. M. Erikson, J. C. Gore, and M. Aschner, "Changes in dietary iron exacerbate regional brain manganese accumulation as determined by magnetic resonance imaging," Toxicological Sciences, vol. 120, no. 1, pp. 146-153, 2011.

[115] E. A. Smith, P. Newland, K. G. Bestwick, and N. Ahmed, "Increased whole blood manganese concentrations observed in children with iron deficiency anaemia," Journal of Trace Elements in Medicine and Biology, vol. 27, no. 1, pp. 6569, 2013.

[116] S. Angeli, T. Barhydt, R. Jacobs, D. W. Killilea, G. J. Lithgow, and J. K. Andersen, "Manganese disturbs metal and protein homeostasis in Caenorhabditis elegans," Metallomics, vol. 6, no. 10, pp. 1816-1823, 2014.

[117] S. Shimoda-Matsubayashi, H. Matsumine, T. Kobayashi, Y. Nakagawa-Hattori, Y. Shimizu, and Y. Mizuno, "Structural dimorphism in the mitochondrial targeting sequence in the human manganese superoxide dismutase gene: a predictive evidence for conformational change to influence mitochondrial transport and a study of allelic association in Parkinson's disease," Biochemical and Biophysical Research Communications, vol. 226, no. 2, pp. 561-565, 1996.

[118] A. Sutton, H. Khoury, C. Prip-Buus, C. Cepanec, D. Pessayre, and F. Degoul, "The Ala16Val genetic dimorphism modulates the import of human manganese superoxide dismutase into rat liver mitochondria," Pharmacogenetics, vol. 13, no. 3, pp. 145-157, 2003.

[119] G. Bresciani, I. B. M. Cruz, J. A. de Paz, M. J. Cuevas, and J. González-Gallego, "The MnSOD Ala16Val SNP: relevance to human diseases and interaction with environmental factors," Free Radical Research, vol. 47, no. 10, pp. 781-792, 2013.

[120] T. Claro da Silva, C. Hiller, Z. Gai, and G. A. Kullak-Ublick, "Vitamin $\mathrm{D}_{3}$ transactivates the zinc and manganese transporter SLC30A10 via the vitamin D receptor," The Journal of Steroid Biochemistry and Molecular Biology, vol. 163, pp. 77-87, 2016.

[121] M. Hajiani, F. Razi, A. Golestani et al., "Time- and dosedependent differential regulation of copper-zinc superoxide dismutase and manganese superoxide dismutase enzymatic activity and mRNA level by vitamin E in rat blood cells," Redox Report, vol. 17, no. 3, pp. 101-107, 2012.

[122] Y. Lv, Y. Zou, J. Liu et al., "Rationale, design and baseline results of the Guangxi manganese-exposed workers healthy cohort (GXMEWHC) study," BMJ Open, vol. 4, no. 7, article e005070, 2014.

[123] Z. Xia, J. Wei, Y. Li et al., "Zebrafish slc30a10 deficiency revealed a novel compensatory mechanism of Atp2c1 in maintaining manganese homeostasis," PLoS Genetics, vol. 13, no. 7, article e1006892, 2017.

[124] P. Chen, M. R. DeWitt, J. Bornhorst et al., "Age- and manganese-dependent modulation of dopaminergic phenotypes in a C. elegans DJ-1 genetic model of Parkinson's disease," Metallomics, vol. 7, no. 2, pp. 289-298, 2015. 


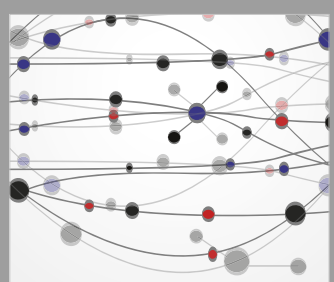

The Scientific World Journal
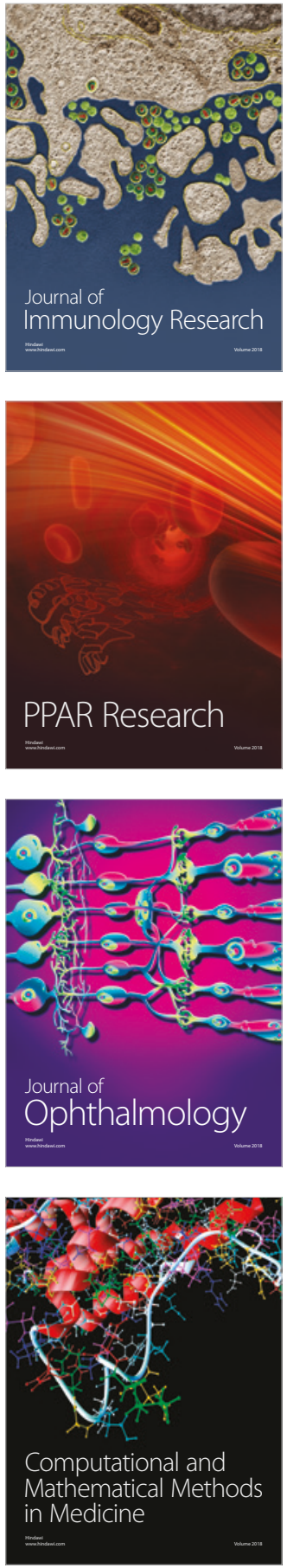

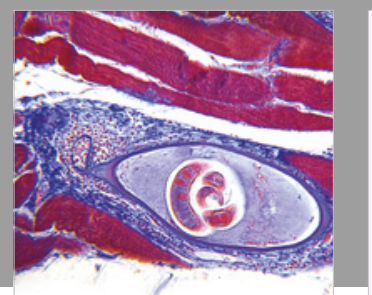

Gastroenterology Research and Practice

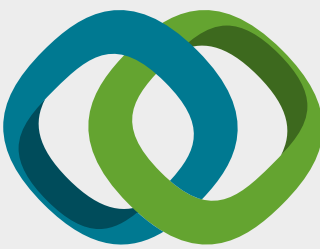

\section{Hindawi}

Submit your manuscripts at

www.hindawi.com
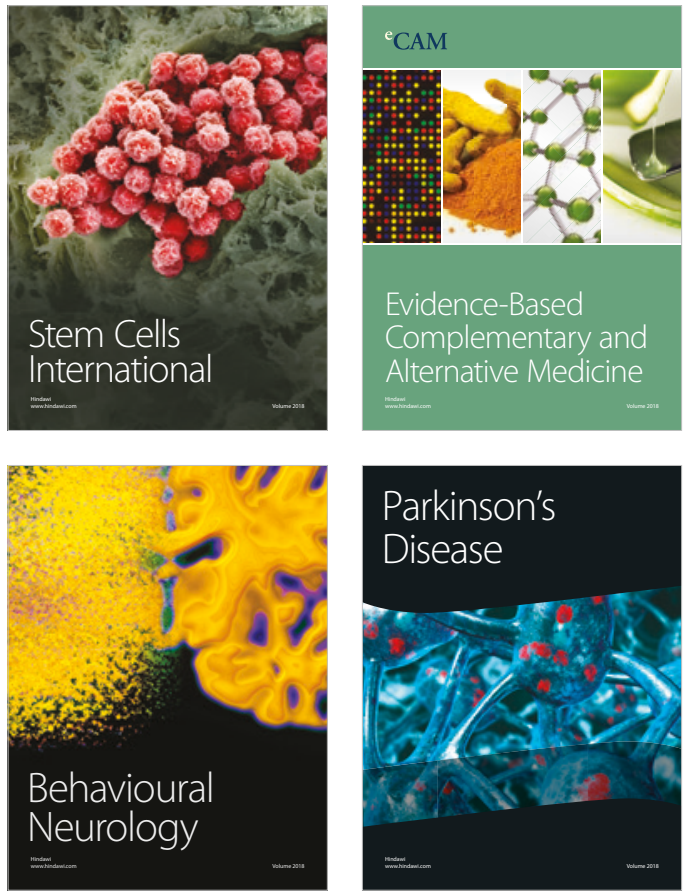

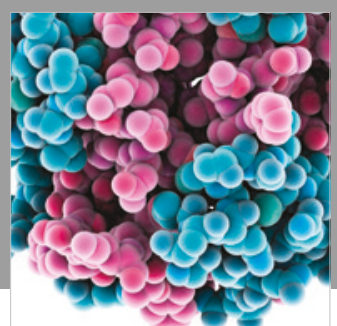

ournal of

Diabetes Research

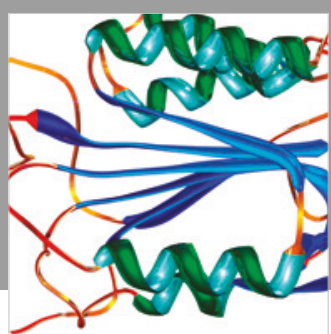

Disease Markers
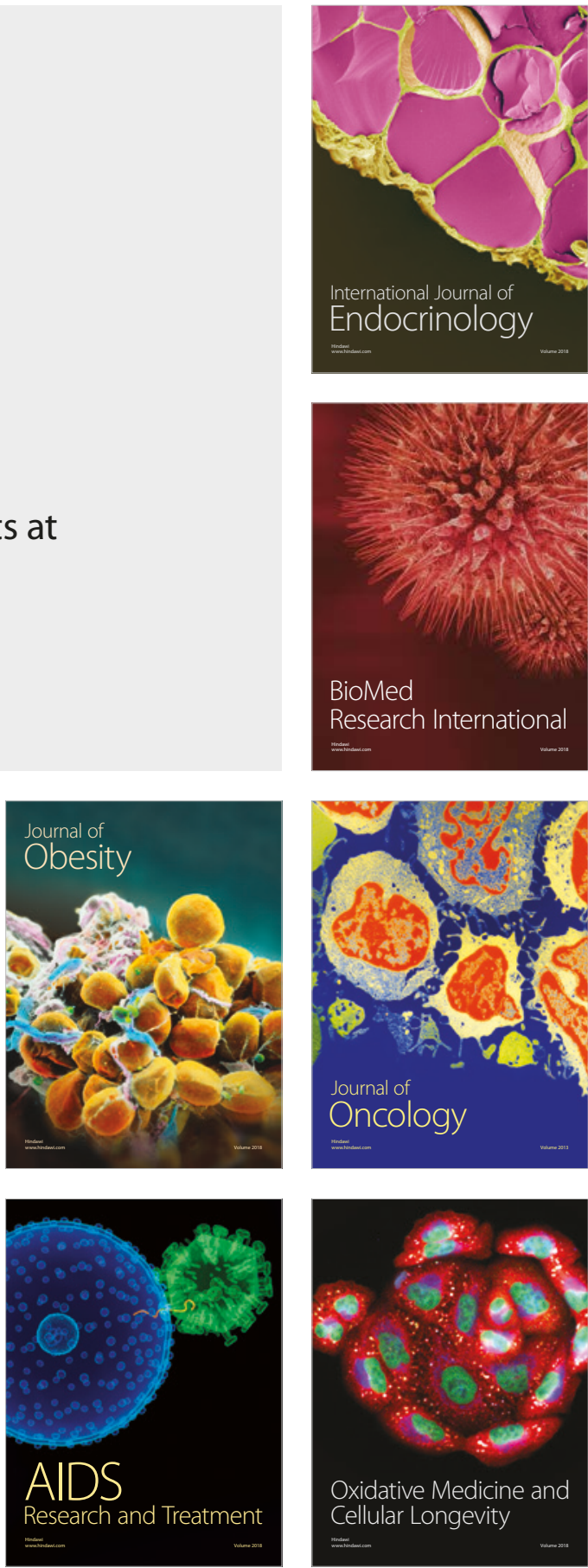